\title{
An inventory of Canadian pregnancy and birth cohort studies: research in progress
}

\author{
Marie-Pier Joly ${ }^{1}$, Michel Boivin², Anne Junker ${ }^{3}$, Alan Bocking ${ }^{4}$, Michael S Kramer ${ }^{5}$ and Stephanie A Atkinson ${ }^{6 *}$
}

\begin{abstract}
Background: A web-based inventory was developed as a voluntary registry of Canadian pregnancy and birth cohort studies, with the objective to foster collaboration and sharing of research tools among cohort study groups as a means to enrich research in maternal and child health across Canada.

Description: Information on existing birth cohort studies conducted in Canada exclusively or as part of broader international initiatives was accessed by searching the literature in PubMed and PsychInfo databases. Additional studies were identified by enquiring about the research activities of researchers at Canadian universities or working in affiliated hospitals or research centres or institutes. Of the fifty-eight birth cohort studies initially identified, forty-six were incorporated into the inventory if they were of a retrospective and/or prospective longitudinal design and with a minimum of two phases of data collection, with the first period having occurred before, during, or shortly after pregnancy and had an initial study sample size of a minimum of 200 participants.

Information collected from each study was organized into four main categories: basic information, data source and period of collection, exposures, and outcome measures and was coded and entered into an Excel spreadsheet. The information incorporated into the Excel spreadsheet was double checked, completed when necessary, and verified for completeness and accuracy by contacting the principal investigator or research coordinator. All data collected were then uploaded onto the website of the Institute of Human Development Child and Youth Health of the Canadian Institutes of Health Research. Subsequently, the database was updated and developed as an online searchable inventory on the website of the Maternal, Infant, Child and Youth Research Network.

Conclusions: This inventory is unique, as it represents detailed information assembled for the first time on a large number of Canadian birth cohort studies. Such information provides a valuable resource for investigators in the planning stages of cohort studies and identifying current research gaps.
\end{abstract}

Keywords: Birth and pregnancy cohort, Maternal health, Infant growth, Child mental development, Inventory

\section{Background}

Prospective longitudinal pregnancy or birth cohort studies exist in many countries to investigate the effect of prenatal, pregnancy, and early postnatal exposures and interventions on maternal health, pregnancy outcomes, and long-term child health, social adjustment, and adult chronic disease. Many such studies are designed to investigate the linkages between environmental and genetic factors and health and disease outcomes in both mother and child. The emergence of several birth cohort studies in Canada prompted two meetings in 2009 that fostered interaction among researchers conducting such

\footnotetext{
*Correspondence: satkins@mcmaster.ca

${ }^{6}$ Department of Pediatrics, McMaster University, Hamilton, ON, Canada

Full list of author information is available at the end of the article
}

studies. The Workshop of the Canadian Birth Cohort Research Network sponsored by the Maternal, Infant, Child and Youth Research Network (MICYRN) had the objective to develop linkages between the existing Canadian birth cohort studies to facilitate interactions and improve the potential for research collaborations [1]. The Workshop on Canadian Children's Environment and Health Research sponsored by Institute of Human Development, Child and Youth Health (IHDCYH) of the Canadian Institutes of Health Research (CIHR) and Health Canada was held to review the (then) current status and future needs for pregnancy/birth cohort studies with measures of exposure to agents of the physicochemical environment.

\section{Biomed Central}

(C) 2012 Joly et al.; licensee BioMed Central Ltd. This is an Open Access article distributed under the terms of the Creative Commons Attribution License (http://creativecommons.org/licenses/by/2.0), which permits unrestricted use, distribution, and reproduction in any medium, provided the original work is properly cited. 
Subsequent to these initial meetings, plans were formulated through a partnership between MICYRN, CIHRIHDCYH and the Strategic Knowledge Cluster on Early Childhood Development (SKC-ECD) to plan and further develop the inventory of seventeen identified birth cohort studies that participated in the MICYRN workshop. Such birth cohort inventories exist in Europe [2]. The initial inventory was then updated [3] and recently expanded to the web-based inventory described in this paper. The actual inventory represents a voluntary registry of Canadian birth cohort studies with the express purpose to serve the research community in its future applications in support of enriching research in maternal and family health as well as broader contexts of well-being such as social capital outcomes.

\section{Construction and content}

\section{Study selection}

The search strategy was not that of a systematic review. Two search strategies were used to identify birth cohort studies conducted in Canada exclusively or as part of broader international initiatives. The first strategy was a keyword search of the existing literature in the databases of PubMed and PsychInfo using various combinations of the following terms "Canada," "birth cohort," "follow up," "longitudinal studies," "birth," "pregnancy," "infant," "newborn," "child," "maternal," "prenatal," "postnatal," "health," and "development." Articles that provided detailed information on a birth cohort study and met the established inclusion criteria were carefully read. The second search strategy involved an enquiry about the research activities of research centers, institutes affiliated with Canadian universities or hospitals and researchers at Canadian universities, primarily in departments of obstetrics and gynecology, pediatrics, psychology, and epidemiology/community health.

Studies were included in the inventory if they were of a retrospective and/or prospective longitudinal design, with a minimum of two phases of data collection. Cross-sectional studies with retrospective data related to pregnancy and birth were not included. The first period of data collection had to have occurred before, during, or shortly after pregnancy including data retrospectively collected. Studies that had early childhood (beyond birth) as the first period of data collection were excluded. However, longitudinal studies conducted among children were included when retrospective data on pregnancy or young infant were collected. The initial subject sample size had to be a minimum of 200 participants. Smaller sample sizes were only included for studies on populations experiencing specific medical conditions, such as in premature babies and on women experiencing depression during pregnancy. For the purpose of this project, no limitation was placed on the number of years participants were enrolled in the study.

\section{Information collected}

Information collected from each study was organized into four main categories: basic information, data source and period of collection, exposures, and outcome measures. Basic information included cohort study title, the principal investigator(s), lead institute(s), enrolment year, enrolment status of the study, study design, initial sample size of mothers, fathers and children, inclusion and exclusion criteria for participants, gestational age at enrolment, source population, coverage, expected duration of follow-up, sample size at each follow-up, and cohort website address.

Data sources included administrative databases, questionnaires, and bio-genetic samples. Data collection periods were categorized into first, second, or third trimester of pregnancy, at birth, 0 to 6 months, 7-18 months, 19-60 months, or 5 or more years after birth. The bio-genetic samples collected included blood, urine, hair, and saliva from mothers, fathers, infants, and children. Samples of placenta, meconium, breast milk, umbilical cord and umbilical cord blood were also noted. Blood samples were indicated as serum, plasma, whole blood, red cells, or white cells.

Exposures were subdivided into social environment (demographic characteristics of parents, family structure and composition, socio-economic status, neighbourhood characteristics, social support, and child care), school environment, social policy, natural environment, indoor environment, and food quality.

Outcomes were subdivided into birth, child, and maternal outcomes. For each of these categories, information was divided into the following subcategories: preterm birth; fetal growth; birth defects; severe neonatal morbidity; neonatal mortality; child growth; acute and chronic illness among children; neurocognitive development; children behavioural problems and mental illness; language development; pregnancy complications; mode of delivery; severe maternal morbidity; and maternal mental health.

Information obtained from each study was coded when necessary and entered into an Excel spreadsheet. Specific variables were assigned to the status of a study ("ongoing," "in development" or "completed") and source population ("selected" (e.g., populations at highrisk or representing a specific medical condition)), "hospital-based," "region-based," "nation-based," or "multinational"). Whether the sample was (a) of convenience, (b) population-based but not necessarily representative, or (c) representative (corrected for biases using population weights) was not categorized. " $\mathrm{Y}$ " or "N," designating "yes" or "no," was attributed to the types and periods of data 
source collection, exposures, and outcomes studied. The validity and reliability of these studies have nonetheless not been evaluated.

The information incorporated into the inventory was verified and validated by contacting the principal investigator or research coordinator by phone or email. A period of one month was allocated to the validation of information, after which a second email was sent to researchers who had not yet responded. In the fall of 2009, all data collected were uploaded on the website of IHDCYH [3].

\section{Web application of the inventory}

Data contained in the Excel spreadsheet were modified according to program established for on-line access. Data in the inventory were updated in August 2010 through contact with the principal investigators or research coordinators of the studies logged in the system.

\section{Results}

Profiles of cohort studies: Of the 58 pregnancy and birth cohort studies initially identified, 46 were validated and incorporated into the inventory. The majority of these studies are either ongoing or in development; only 11 had been completed at the time the inventory was created. In total, these 46 birth cohort studies involve over 950,000 mothers, 24,000 fathers, and 1 million children; $78 \%$ of the studies have an initial sample size greater than 1000 participants. To our knowledge, only two studies were conducted among participants from a previous cohort, both of which are included in the inventory. The Emigarde project [4] drew on subjects from the Montreal Prematurity Project [5,6] and the SAGE nested case control study drew on the SAGE study [7]. The most common source population is region-based (61\%), followed by hospital-based (16\%), selected (9\%), nation-based (7\%) and multi-national (7\%). Coverage of geographical locations within Canada was noticeably diverse. As demonstrated in Figure 1, most studies have collected data in the provinces of Ontario (44.1\%) and Quebec (32.6\%). The percentage of studies conducted in Saskatchewan, Manitoba, Alberta, and British Columbia range from $11.6-18.6 \%$. Considerably less attention is devoted to the Eastern provinces and the Territories. The majority of participants have been enrolled over the last two decades, with the exception of two studies for which enrolment started in late 1970s.

Data collection: Although certain studies had only one means to collect their data, several studies used more than one method. While $37 \%$ of birth cohort studies rely on administrative databases such as the Quebec Pregnancy Registry and the London Perinatal Database Retrospective, $87 \%$ of studies collect their data through questionnaires and $54 \%$ of studies include bio-genetic samples. The most common period for data collection with questionnaires was 0-6 months after birth (63\%), and the most common period for collecting bio-genetic samples was at birth (34.8\%) (Figure 2).

The environmental exposures varied widely across studies (Figure 3). Forty-four studies (95\%) included measures of social environment, while natural and indoor environment measures were included only in 9 and 6 studies, respectively.

Key outcome measures included pregnancy complications (43 studies), severe maternal morbidity (30 studies), birth defects (31 studies), and neonatal morbidity/

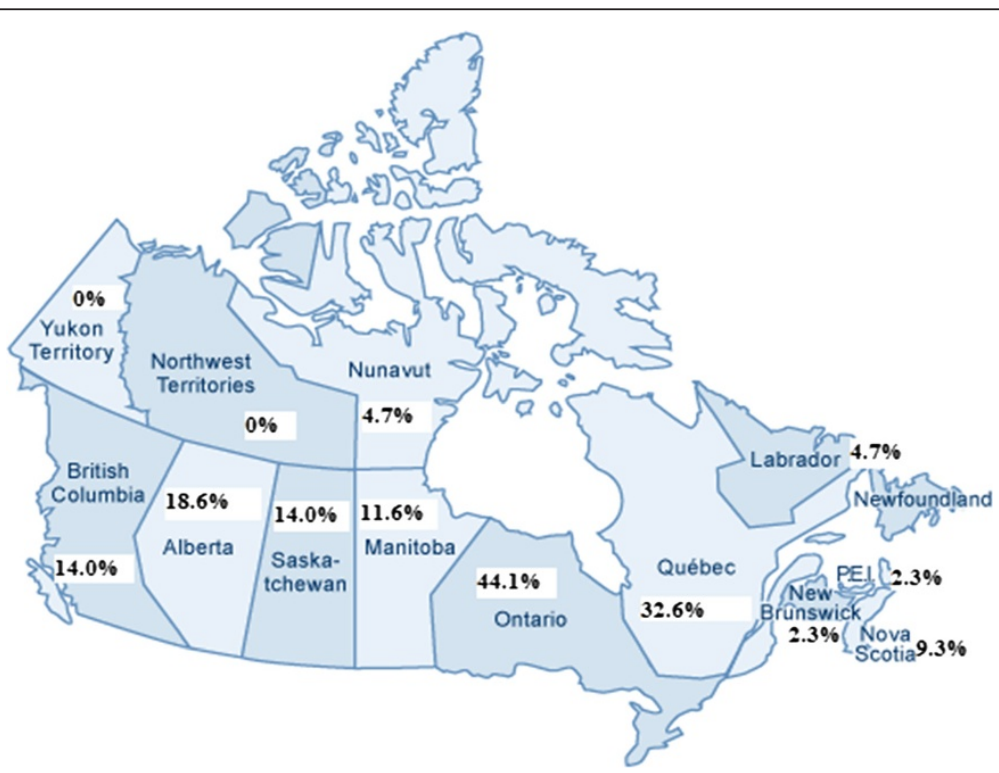

Figure 1 Percent of birth cohort studies conducted by province and territory. Some studies cover more than one province or territory. 


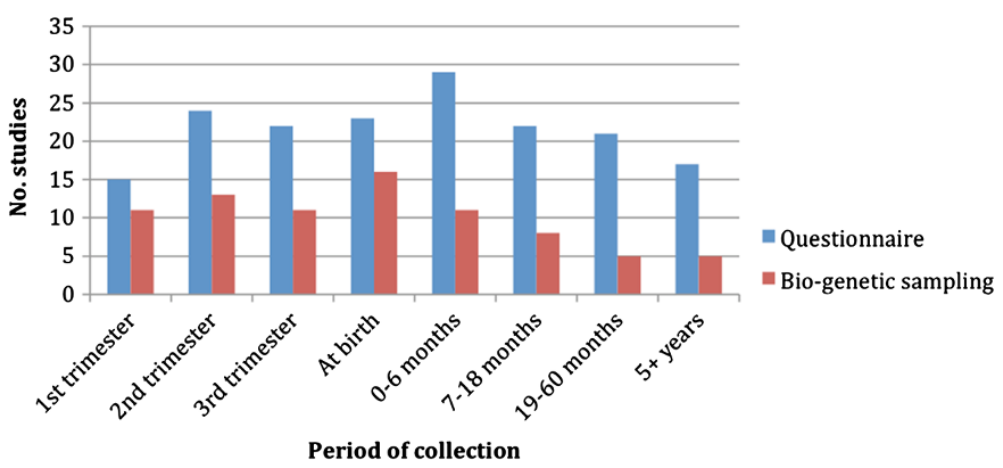

Figure 2 Periods of data collection used for questionnaires and bio-genetic sampling in birth cohort studies. Included studies were required to use at least two periods of data collection.

mortality (34 studies), neurocognitive development (26 studies), and behavioural problems and mental illness among children (27 studies).

The types of bio-genetic samples collected at various intervals in pregnancy and infancy varied across studies (Table 1). Umbilical cord blood was the bio-genetic sample collected by most studies (30.4\%), while maternal blood was collected over various time periods. Biogenetic samples have seldom been collected from fathers.

\section{Utility}

The web application online searchable inventory not only facilitates the search for information, but also the management of the inventory. Studies can be retrieved by selecting a particular type of biological sample, exposure, or outcome of interest. The search can be restricted by choosing a combination of measures under these three categories or by entering a keyword. The inventory also represents an important tool to foster potential and eventual collaborations among researchers. Among the array of information available from this inventory is information about the possibility for sharing the biobank and for research collaboration. Interested researchers can explore the complete inventory to examine such possibilities.

\section{Discussion}

The current online cohort inventory provides key information stemming from 46 pregnancy and birth cohort studies that have incorporated a large number of subjects studied across diverse geographical locations in Canada. Types of exposures, outcomes, and biological samples are the key information elements available in the inventory. While nearly one million mothers and their offspring have been recruited in total across the 46 studies, not all subjects would be available for future contact. However, for studies still ongoing, re-consent might be possible if additional follow-up was desirable.

This inventory is unique, as it represents detailed information assembled for the first time on a large range of Canadian birth cohort studies. As well, the content and format is aligned with inventories from Europe [2] and others designed with a genetics focus including the Public Population Project in Genomics $\left(\mathrm{P}^{3} \mathrm{G}\right)$, which supports the development and harmonization of epidemiological projects in genomics [8]. This alignment should facilitate assembly of information across existing published cohort study inventories.

The inventory also reveals major gaps in research. While most studies have collected data on the social environment of participants, data on the natural and indoor environment has been infrequently assessed. Despite the geographical coverage of studies extending across Canada, most are from Ontario or Quebec, and few include populations from the Eastern provinces or the Territories. In addition, few studies had immediate plans for genetic analysis, although some indicated banking of biological samples for possible future analysis.

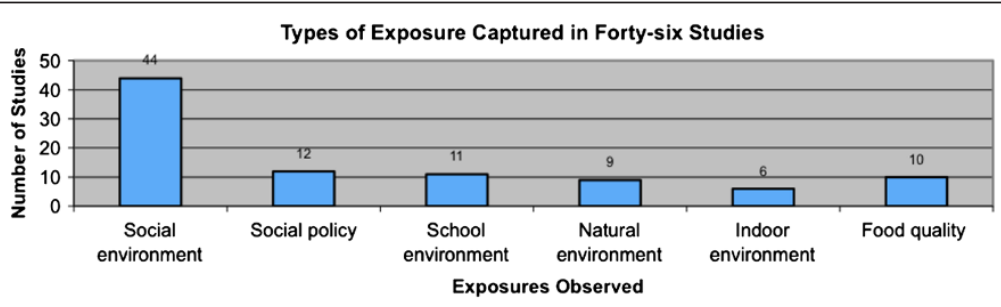

Figure 3 Categories of environmental exposure settings in Canadian birth cohort studies. 
Table 1 Number of birth cohort studies that collected bio-genetic samples at various time periods

\begin{tabular}{|c|c|c|c|c|c|c|c|c|}
\hline \multirow[t]{3}{*}{ Biogenetic sample } & \multicolumn{8}{|c|}{ Time period; no. (\%) of studies } \\
\hline & \multicolumn{8}{|c|}{$n=46$} \\
\hline & $1^{\text {st }}$ & $2^{\text {nd }}$ & $3^{\text {rd }}$ & At & $0-6$ & $7-18$ & $19-60$ & $5+$ \\
\hline & Trimester & Trimester & Trimester & Birth & Months & Months & Months & Years \\
\hline \multirow[t]{2}{*}{ Maternal blood } & 8 & 11 & 9 & 7 & 3 & 4 & 2 & 1 \\
\hline & $(17.4 \%)$ & $(23.9 \%)$ & $(19.6 \%)$ & $(15.2 \%)$ & $(6.5 \%)$ & $(8.7 \%)$ & $(4.3 \%)$ & $(2.2 \%)$ \\
\hline \multirow[t]{2}{*}{ Paternal blood } & 1 & 1 & 1 & - & - & - & 1 & 3 \\
\hline & $(2.2 \%)$ & $(2.2 \%)$ & $(2.2 \%)$ & & & & $(2.2 \%)$ & $(6.5 \%)$ \\
\hline \multirow[t]{2}{*}{ Cord blood } & - & - & - & 14 & - & - & - & - \\
\hline & & & & $(30.4 \%)$ & & & & \\
\hline \multirow[t]{2}{*}{ Placenta } & - & - & - & 9 & - & - & - & - \\
\hline & - & - & - & $(19.6 \%)$ & - & - & - & - \\
\hline \multirow[t]{2}{*}{ Umbilical cord } & - & - & - & 3 & - & - & - & - \\
\hline & - & - & - & $(6.5 \%)$ & - & - & - & - \\
\hline \multirow[t]{2}{*}{ Offspring blood } & - & - & - & - & 4 & 2 & 3 & 4 \\
\hline & & & & & $(8.7 \%)$ & $(4.3 \%)$ & $(6.5 \%)$ & $(8.7 \%)$ \\
\hline \multirow[t]{2}{*}{ Meconium } & - & - & - & 5 & - & - & - & - \\
\hline & & & & $(10.9 \%)$ & & & & \\
\hline \multirow[t]{2}{*}{ Breast milk } & - & - & - & - & 6 & - & - & - \\
\hline & & & & & $(13.0 \%)$ & & & \\
\hline \multirow[t]{2}{*}{ Maternal urine } & 5 & 5 & 5 & 2 & - & - & - & - \\
\hline & $(10.9 \%)$ & $(10.9 \%)$ & $(10.9 \%)$ & $(4.3 \%)$ & & & 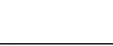 & \\
\hline \multirow[t]{2}{*}{ Paternal urine } & 1 & - & - & - & - & - & - & - \\
\hline & $(2.2 \%)$ & & & & & & & \\
\hline \multirow[t]{2}{*}{ Offspring urine } & - & - & - & - & 2 & 1 & 1 & 2 \\
\hline & & & & & $(4.3 \%)$ & $(2.2 \%)$ & $(2.2 \%)$ & $(4.3 \%)$ \\
\hline \multirow[t]{2}{*}{ Maternal hair } & 3 & 2 & 1 & 3 & 2 & 1 & 1 & - \\
\hline & $(6.5 \%)$ & $(4.3 \%)$ & $(2.2 \%)$ & $(6.5 \%)$ & $(4.3 \%)$ & $(2.2 \%)$ & $(2.2 \%)$ & \\
\hline \multirow[t]{2}{*}{ Paternal hair } & - & - & - & - & - & 1 & - & - \\
\hline & - & - & - & - & - & $(2.2 \%)$ & - & - \\
\hline \multirow[t]{2}{*}{ Offspring hair } & - & - & - & 1 & 1 & 1 & 1 & 1 \\
\hline & & & & $(2.2 \%)$ & $(2.2 \%)$ & $(2.2 \%)$ & $(2.2 \%)$ & $(2.2 \%)$ \\
\hline \multirow[t]{2}{*}{ Maternal saliva } & 2 & 1 & 1 & - & 2 & 3 & 1 & 1 \\
\hline & $(4.3 \%)$ & $(2.2 \%)$ & $(2.2 \%)$ & & $(4.3 \%)$ & $(6.5 \%)$ & $(2.2 \%)$ & $(2.2 \%)$ \\
\hline \multirow[t]{2}{*}{ Paternal saliva } & - & 1 & - & - & - & - & 1 & 1 \\
\hline & & $(2.2 \%)$ & & & & & $(2.2 \%)$ & $(2.2 \%)$ \\
\hline \multirow[t]{2}{*}{ Offspring saliva } & - & - & - & - & 1 & 3 & 3 & 2 \\
\hline & & & & & $(2.2 \%)$ & $(6.5 \%)$ & $(6.5 \%)$ & $(4.3 \%)$ \\
\hline \multirow[t]{2}{*}{ Maternal nails } & - & - & 1 & - & - & - & - & - \\
\hline & & & $(2.2 \%)$ & & & & & \\
\hline Paternal nails & - & - & - & - & - & - & - & - \\
\hline Offspring nails & - & - & - & - & - & - & - & - \\
\hline
\end{tabular}

Output from the cohort workshops clearly identified the sharing of research tools as a key element that might be accommodated in future development of the online inventory. To evaluate that potential, we conducted a literature search of selected studies represented in the current inventory to determine the extent to which measurement tools currently employed were consistent across studies. This was accomplished by reviewing papers published by the cohorts that cited the measurement tools used. Researchers have drawn upon an array of scales, tests, and assessments to measure health outcomes 
Table 2 Outcomes measures from selected studies

\begin{tabular}{|c|c|c|c|}
\hline Name of study & $\begin{array}{l}\text { Birth outcomes } \\
\text { measures }\end{array}$ & Child outcomes measures & Maternal outcomes measures \\
\hline $\begin{array}{l}\text { Better Beginnings, } \\
\text { Better Futures [9] }\end{array}$ & & $\begin{array}{l}\text { Social Skills Rating Scales [10]; Revised Ontario Child Health } \\
\text { Study [11]; Peabody Picture Vocabulary Test [12]; Wechsler } \\
\text { Intelligence Scale for Children- Revised [13]; Wide Range of } \\
\text { Achievement Test [14]; Scale of Reading Attitude [15] }\end{array}$ & \\
\hline $\begin{array}{l}\text { Community Perinatal } \\
\text { Care Study [16] }\end{array}$ & & $\begin{array}{l}\text { Pediatric Evaluation of Developmental Status (PEDS) [17]; } \\
\text { Child Social Competence Scale [18]; SF-8 Health Survey [19] }\end{array}$ & $\begin{array}{l}\text { Edinburgh Posnatal Depression } \\
\text { Scale (EPDS) [20] }\end{array}$ \\
\hline $\begin{array}{l}\text { Ice Storm Project } \\
\text { [21-23] }\end{array}$ & & $\begin{array}{l}\text { Mental Scale of the Bayley Scales of Infant Development (2nd } \\
\text { Ed.) [24]; MacArthur Communicative Development Inventory } \\
\text { (MCDI) [25]; Wechsler Preschool and Primary Scale of } \\
\text { Intelligence-Revised (WPPSI-R) [26]; Peabody Picture } \\
\text { Vocabulary Test-Revised (PPVT-R) [27] }\end{array}$ & $\begin{array}{l}\text { Impact of Event Scale-Revised } \\
\text { (IES-R) [28]; General Health } \\
\text { Questionnaire (GHQ) [29]; } \\
\text { Edinburgh Postnatal Depression } \\
\text { Scale (EPDS) [20] }\end{array}$ \\
\hline $\begin{array}{l}\text { The International } \\
\text { Randomized Term } \\
\text { Breech Trial [30,31] }\end{array}$ & & Ages and Stages Questionnaire (ASQ) [32] & $\begin{array}{l}\text { Edinburgh Posnatal Depression } \\
\text { Scale (EPDS) [20] }\end{array}$ \\
\hline $\begin{array}{l}\text { Ottawa Prenatal } \\
\text { Prospective Study } \\
\text { (OPPS) [33-35] }\end{array}$ & $\begin{array}{l}\text { Brazelton } \\
\text { Neonatal } \\
\text { Assessment } \\
\text { Scale [36] }\end{array}$ & $\begin{array}{l}\text { Bayley Scales of Infant Development [37]; Reynell } \\
\text { Developmental Language Scales [38]; } \\
\text { Prechtl assessment [39] }\end{array}$ & \\
\hline $\begin{array}{l}\text { The Ontario Mother and } \\
\text { Infant Study (TOMIS) III [40] }\end{array}$ & & & $\begin{array}{l}\text { Edinburgh Posnatal Depression } \\
\text { Scale (EPDS) [41] }\end{array}$ \\
\hline $\begin{array}{l}\text { Victimization: A Newly } \\
\text { Recognized Outcome of } \\
\text { Prematurity [42] }\end{array}$ & & $\begin{array}{l}\text { McCarthy Scales of Children's Abilities [43] } \\
\text { Hunttenlocher neurological task test [44] }\end{array}$ & \\
\hline $\begin{array}{l}\text { Family Atherosclerosis } \\
\text { Monitoring in Early Life } \\
\text { (FAMILY) [45] }\end{array}$ & & Habitual Activity Estimation Scale (HAES) [46] & Food Frequency Questionnaire [47] \\
\hline
\end{tabular}

(Table 2). The child and maternal outcome measures studied shared several published questionnaires and scales (Table 2).

The selected review of measurement tools employed in the cohort studies included in the inventory revealed some consistency for measures of infant and child neurocognitive, education and social skills and of maternal depression. Clearly, there is great opportunity for sharing of other validated tools, such as quantitative assessment of dietary intake, physical activity, or relevant environmental influences.

\section{Conclusions}

The current inventory represents only a first step. MICYRN and its partners, including the SKC-ECD will update and expand the inventory. Future expansion could include a repository for measurement tools, such as questionnaires and analytical methods, which could be shared with other studies and available upon registration in the MICYRN Birth Cohort Inventory. Such collaborations could improve validity and quality assurance of measurement tools. Finally, linkage of birth cohort databases to health care and other databases could also be facilitated by MICYRN to provide expanded opportunities for in-depth analysis.

\section{Availability and requirements}

The online inventory is publically available and can be accessed at http://www.micyrn.ca/Networks.asp\#2. The inventory can be searched at http://www.micyrn. $\mathrm{ca} /$ databases/cohortsearch.asp by type of Biological Samples, Exposures or Outcomes, and by Keyword. There is a link to a spreadsheet view of the complete inventory and a more detailed view of all data being collected in the complete inventory. Researchers are welcome to contribute to the development of the inventory by registering their cohort study, which meet our criteria of inclusion, at the following link http://www.micyrn.ca/ databases/asplogin/CohortLogin.asp\#2. Submitted forms return to the MICYRN Secretariat and are reviewed prior to entry into the Inventory to ensure they meet the original criteria set for study selection as described in the Background. Future expansion of the inventory will include an international scope.

\section{Abbreviations}

MICYRN: Maternal, Infant, Child and Youth Research Network; IHDCYH: Institute of Human Development, Child and Youth Health;

CIHR: Canadian Institutes of Health Research; SKC-ECD: Strategic Knowledge Cluster on Early Childhood Development; $\mathrm{P}^{3} \mathrm{G}$ : Public Population Project in Genomics.

\section{Competing interests}

The authors declare that they have no competing interests. 


\section{Authors' contributions}

SA initiated the pregnancy and Canadian birth cohort network and inventory and was responsible for the development of the manuscript and oversight of its completion and submission. AB was co-initiator of cohort network and reviewed the manuscript. $\mathrm{MB}$ contributed to the development of the inventory and reviewed the manuscript. M-P J conducted the literature search to identify the expanded cohort database and contributed to the establishment of the inventory within the Canadian Institutes for Health Research (CIHR) Institute of Human Development, Child and Youth Health $(\mathrm{IHDCYH})$ and took a primary role in the writing and revisions of the manuscript. AJ facilitated the establishment of the online searchable inventory on the website of the Maternal, Infant, Child and Youth Research Network and reviewed the manuscript. MK facilitated the development of the inventory as a project within the CIHR IHDCYH. All authors read and approved the final manuscript.

\section{Authors' information}

M-P J contributed initially to this project when a study analyst for the Institute of Human Development, Child and Youth Health at the Canadian Institutes of Child Health in Ottawa, Canada. She is currently a PhD student in the department of sociology at the University of Toronto.

\section{Acknowledgments}

The authors gratefully acknowledge the contributions of others who participated in information gathering and compilation of the inventory.

\section{Author details}

'Department of Sociology, University of Toronto, Toronto, ON, Canada. 2École de psychologie, Université Laval, Quebec, PQ, Canada. ${ }^{3}$ Department of Pediatrics, University of British Columbia, Vancouver, BC, Canada. ${ }^{4}$ Department of Obstetrics \& Gynecology, University of Toronto, Toronto, ON, Canada. ${ }^{5}$ Departments of Pediatrics and of Epidemiology, Biostatistics and Occupational Health, McGill University, Montreal, PQ, Canada. ${ }^{6}$ Department of Pediatrics, McMaster University, Hamilton, ON, Canada.

Received: 24 July 2012 Accepted: 22 October 2012 Published: 29 October 2012

\section{References}

1. Atkinson SA, Bocking A: Birth Cohorts Workshop Report. http://www.micyrn ca/PDF/Can_Birth_Cohorts_RN_Workshop_MICYRN_FINAL.pdf.

2. Birth Cohorts.net. www.birthcohorts.net.

3. Inventory of Pregnancy and Birth Cohort Studies in Canada. 2009 http://www.cihr-irsc.gc.ca/e/40753.html.

4. Ouellet-Morin I, Tremblay RE, Boivin M, Meaney M, Kramer M, Côté SM: Diurnal cortisol secretion at home and in child care: a prospective study of 2-year-old toddlers. J Child Psychol Psychiatry 2010, 51:295-303.

5. Kramer MS, Wilkins R, Goulet L, Séguin L, Lydon J, Kahn SR, for the Montreal Prematurity Study Group, et al: Investigating socio-economic disparities in preterm birth: evidence for selective study participation and selection bias. Paediatr Perinat Epidemiol 2009, 23:301-309.

6. Kramer MS, Goulet L, Lydon J, Séguin L, McNamarar H, Dassa C, Platt RW et al: Socio-economic disparities in preterm birth: causal pathways and mechanisms. Paediatr Perinat Epidemiol 2001, 15:104-123.

7. Kozyrskyj AL, Hayglass KT, Sandford AJ, Paré PD, Chang-Yeung M, Becker AB: A novel study design to investigate the early-life origins of asthma in children (SAGE Study). Allergy 2009, 64:1185-1193.

8. Public Population Project in Genomics. http://www.p3gobservatory.org/ catalogs.htm.

9. Peters RDV, Petrunka K, Arnold R: The Better Beginnings, Better Futures Project: a universal, comprehensive, community-based prevention approach for primary school children and their families. J Clin Child Adolesc Psychol 2003, 32:215-227.

10. Gresham FM, Elliot SN: Social skills rating system manual. Circle Pines, MN: American Guidance Services; 1990.

11. Boyle MH, Offord DR, Racine $Y$, Fleming JE, Szatmari P, Sanford M: Evaluation of the revised Ontario child health study scales. J Child Psychol Psychiatry 1993, 34:189-213.

12. Dunn LM, Dunn LM: Peabody picture vocabulary test-revised. Circle Pines, MN: American Guidance Services; 1981.
13. Wechsler P: Wechsler intelligence scale for children-revised (WISC-R). New York: Psychological Corporation; 1974.

14. Jastak S, Wilkinson GS: Wide range achievement test-revised. Wilmington, DE: Jastak Associates; 1984

15. Rowell CG: An attitude scale for reading. Read Teach 1972, 25:442-447.

16. Tough SC, Siever J: Community Perinatal Care Follow Up Study at 5 Years: Final Report. Submitted to Calgary Children's Initiative and the Calgary Health Region. 2008. http://people.ucalgary.ca/ stough/Reports/CPC5.pdf.

17. Glascoe FP: PEDS: Parents' evaluation of developmental status. 2005. www pedstest.com.

18. Corrignan A: Social competence scale-parental version, grade 1/year2 (fast track project technical report). 2002. http://www.fasttrackproject.org/techrept/ s/scp/scp2tech.pdf.

19. Ware JE, Kosinski M, Deway JE, Gandek B: How to score and interpret single item health status measures. Lincoln, Rl: Quality Metric Incorporated; 2001.

20. Cox JL, Holden JM, Sagovsky R: Detection of postnatal depression.

Development of the 10-item Edinburgh postnatal depression scale. $\mathrm{Br}$ Psychiatry 1987, 150:782-786.

21. Laplante DP, Baar RG, Brunet A, Galbaud Du Fort G, Meaney ML, Saucier J-F, et al: Stress during pregnancy affects general intellectual and language functioning in human toddlers. Pediatr Res 2004, 56:400-410.

22. King S, Laplante DP: The effects of prenatal maternal stress on children's cognitive development: Project Ice Storm. Stress 2005, 8:35-45.

23. Laplante DP, Brunet A, Schmitz N, Ciampi A, King S: Project Ice Storm: prenatal maternal stress affects cognitive and linguistic functioning in 51/2-year old children. J Am Acad Child Adolesc Psychiatry 2008, 47:1063-1072.

24. Bayley N: Bayley scales of infant development. 2nd edition. San Antonio: The Psychological Corporation; 1993.

25. Fenson L, Dale PS, Reznick JS, Thal D, Bates E, Hartung JP, et al: MacArthur communicative development inventories. San Diego: Singular Publishing Group; 1993.

26. Wechsler D: Wechsler preschool and primary scale of intelligence-revised. San Antonio: Psychological Corporation; 1989.

27. Dunn LM, Dunn LM: PPVT: peabody picture vocabulary test-revised: manual for forms $L$ and M. Circle Pines, MN: American Guidance Services; 1981.

28. Weiss DS, Marmar CR: The impact of event scale-revised. New York: Guilford; 1997.

29. Goldberg DP: The detection of psychiatric illness by questionnaire: a technique for the identification and assessment of non-psychiatric illness. London: Oxford University Press; 1972.

30. Whyte H, Hannah ME, Saigal S, Hannah WJ, Hewson S, Amankwah K, et al: Outcomes of children at 2 years after planned caesarean birth versus planned vaginal birth for breech, presentation at term: The International Randomized Term Breech Trial. Am J Obstet Gynecol 2004, 191:864-871.

31. Hannah ME, Hannah WJ, Hodnett ED, Chalmers B, Kung R, Willan A, et al Outcomes at 3 months after planned caesarean vs planned vaginal delivery for breech presentation at term: The International Randomized Term Breech Trial. JAMA 2002, 287:1822-1831.

32. Squires J, Potter L, Bricker D: The ASO user's quide for the ages \& stages questionnaires: a parent-completed, child-monitoring system. Baltimore (MD): Paul H Brookes Publishing Col; 1995.

33. Fried PA: Marihuana use by pregnant women: neurobehavioral effects in neonates. Drug Alcohol Depend 1980, 6:415-424.

34. Fried PA, Watkinson B: 12- and 24-month neurobehavioural follow-up of children prenatally exposed to marihuana, cigarettes, and alcohol. Neurotoxicol Teratol 1988, 10:305-313.

35. Fried PA, Watkinson B, Dillon RF, Dulberg CS: Neonatal neurological status in a low- risk population after prenatal exposure to cigarettes, marijuana, and alcohol. J Dev Behav Pediatr 1987, 8:318-326.

36. Brazelton TB: Neonatal behavioral assessment scale. London: William Heinemann \& Sons; 1973

37. Bayley N: Bayley scales of infant development. New York: Psychological Corporation; 1969

38. Reynell J: Reynell developmental language scales. Windsor, Bershire: NFER: 1969.

39. Prechtl HFR: The neurological examination of the full-term newborn infant, $2^{\text {nd }}$ ed Clinics in Developmental Medicine, no. 63. Philadelphia: Lippincott; 1977.

40. Sword W, Watt S, Krueger P, Thabane L, Landy CK, Farine D, et al: The Ontario Mother and Infant Study (TOMIS) III: a multi-site cohort study of 
the impact of delivery method on health, service use, and costs of care in the first postpartum year. BMC Pregnancy Childbirth 2009, 9:16.

41. Cox J, Holden J: Perinatal mental health: a guide to the Edinburgh postnatal depression scale. United Kingdom: Gaskell Publishing; 2003.

42. Nadeau L, Lefebvre F, Robaey P: Victimization: a newly recognized outcome of prematurity. Dev Med Child Neurol 2004, 46:508-513.

43. McCarthy D: The McCarthy scales of children's abilities. New York: Psychological Corporation; 1972.

44. Huttenlocher PR, Levine SC, Huttenlocher J, Gates J: Discrimination of normal and at- risk preschool children on the basis of neurological tests. Dev Med Child Neurol 1990, 32:394-402.

45. Morrison K, Atkinson SA, McDonald S, Yusuf S, Persadie R, Hunter B, Teo K, the FAMILY investigators: The FAMILY Atherosclerosis Monitoring In Early Life (FAMILY) Study: Rationale, Design and Baseline Data. Am Heart J 2009, 158(4):533-539.

46. Hay J, Cairney J: Development of the habitual activity estimation scale for clinical research: A systematic approach. Pediatr Exerc Sci 2006, 18:193.

47. Kelemen LE, Anand SS, Vuksan V, Yi Q, Teo KK, Devanesen S, Yusuf S, SHARE investigators: Development and evaluation of cultural food frequency questionnaires for South Asians, Chinese, and Europeans in North America. J Am Diet Assoc 2003, 103(9):1178-1184.

\section{doi:10.1186/1471-2393-12-117}

Cite this article as: Joly et al: An inventory of Canadian pregnancy and birth cohort studies: research in progress. BMC Pregnancy and Childbirth 2012 12:117.

\section{Submit your next manuscript to BioMed Central and take full advantage of:}

- Convenient online submission

- Thorough peer review

- No space constraints or color figure charges

- Immediate publication on acceptance

- Inclusion in PubMed, CAS, Scopus and Google Scholar

- Research which is freely available for redistribution 